ISSN 0103-8478

\title{
In vitro germination and acclimatization of cambui tree type seedlings
}

\author{
Germinação in vitro e aclimatização de tipos de cambuizeiro
}

\author{
Ana da Silva Lédo ${ }^{\mathrm{I}}$ Luciana Borin Barin ${ }^{\mathrm{II}}$ Ana Veruska Cruz da Silva \\ Francielen Paola de Sá ${ }^{I I I}$ Caroline de Araújo Machado ${ }^{I V}$
}

\section{ABSTRACT}

There are few reports in literature on the in vitro behavior of cambui tree (Myrciaria tenella O. Berg) and acclimatization conditions. The aim of this study was to evaluate the effect of culture media on in vitro germination and the effect of different substrates on the acclimatization of two Myrciaria tenella types. The study was carried out at the Embrapa Tabuleiros Costeiros Laboratory of Plant Tissue Culture, Aracaju, SE. Seeds were extracted from fruits of two Myrciaria tenella types: Orange and Purple Types. The seeds were inoculated in the following culture media: T1 - MS medium + 30g $L^{-1}$ sucrose, T2 - 1/2 MS medium $+15 \mathrm{~g} \mathrm{~L}^{-1}$ sucrose and T3 - control without MS salts. To study the effect of substrates on acclimatization, seedlings were transferred to plastic containers with capacity of $300 \mathrm{~cm}^{3}$ containing the following sterilized substrates: S1 - soil and powdered coconut husk - SPC (1:1 by volume); S2 - soil, washed sand and powdered coconut husk - SAPC (1:1:1 by volume) and S3 - Biomix ${ }^{\circledR}$ commercial substrate - SC. The medium without MS salts promoted $100 \%$ in vitro germination and $1 / 2$ MS medium greater development of seedlings. All substrates studied are suitable for acclimatization of seedlings germinated in vitro. Myrciaria tenella of yellow type showed greater vigor during acclimatization.

Key words: Myrciaria tenella O. Berg, in vitro propagation, substrates, fruticulture.

\section{RESUMO}

São poucos os relatos na literatura sobre estudos do comportamento do cambuizeiro (Myrciaria tenella O. Berg) in vitro e condições de aclimatação. O objetivo do trabalho foi de avaliar o efeito de meios de cultura na germinação in vitro e o efeito de diferentes substratos na aclimatação de tipos de cambuizeiros. $O$ estudo foi realizado no Laboratório de Cultura de Tecidos de Plantas da Embrapa Tabuleiros Costeiros, Aracaju,
SE. Foram utilizadas sementes extraídas de frutos de dois tipos de cambuizeiros: Tipo Laranja e Tipo Roxo. Para o estudo de meios para a germinação, as sementes foram inoculadas nos seguintes meios de cultura: $\mathrm{T} 1$-meio de $\mathrm{MS}+30 \mathrm{~g} \mathrm{~L}^{-1}$ de sacarose, T2 meio $1 / 2 \mathrm{MS}+15 \mathrm{~g} \mathrm{~L}^{-1}$ de sacarose e T3-testemunha sem sais MS. Para o estudo do efeito de substratos na aclimatação, as plântulas foram transferidas para recipientes plásticos com capacidade de $300 \mathrm{~cm}^{3}$, contendo os seguintes substratos esterilizados: 51 - solo e pó de casca de coco seco - SPC (1:1, em volume); S2 -solo, areia lavada e pó de casca de coco seco - SAPC (1:1:1, em volume); e S3-substrato comercial Biomix ${ }^{\circledR}$ - SC. O meio sem sais MS proporciona $100 \%$ porcentagem de germinação in vitro e o meio $1 / 2$ MS maior desenvolvimento em altura de plântulas. Todos os substratos estudados são adequados para aclimatação de plântulas germinadas in vitro. O cambuizeiro do tipo Amarelo apresenta maior vigor na aclimatação.

Palavras-chave: Myrciaria tenella O. Berg, propagação in vitro, substratos, fruticultura.

\section{INTRODUCTION}

Among the fruit species native to Brazil that are little known regarding sources of nutrients, the cambui tree (Myrciaria tenella O. Berg) stands out, belonging to the family Myrtaceae, which occurs from Maranhão down to Rio Grande do Sul, Brazil, extending up to Argentina. Some natural populations have already been observed in Sergipe, specifically in Itaporanga d'Ajuda and Pirambu regions (PINHEIRO et al., 2011). Its fruits are glabrous and bright globose berries, red or dark purplish when ripe. Besides the

\footnotetext{
'Embrapa Tabuleiros Costeiros, 490250-040, Aracaju, SE, Brasil. E-mail: ana.ledo@embrapa.br. *Autor para correspondência.

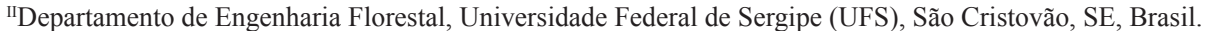

"IIPrograma de Pós-graduação em Biotecnologia de Recursos Naturais, UFS, São Cristovão, SE, Brasil.

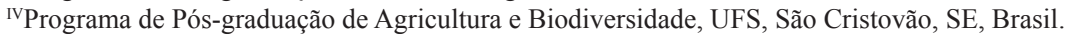


production of fruits, it has importance to landscaping and timber production (LORENZI, 2000), also being source of vitamin C (PINHEIRO et al., 2011) and having anti-inflammatory activity (APEL et al., 2010).

There are few reports in literature on the in vitro behavior of Myrciaria tenella and acclimatization conditions. The species is still in the domestication process and therefore all aspects related to its cultivation still need further studies. In vitro propagation technologies well developed and/or adapted for Myrciaria tenella are of great importance for conservation programs of genetic resources and genetic improvement of the species.

The establishment of protocols for the micropropagation of woody species from explants originating from plants grown in vitro is more feasible under the physiological and experimental point of view due to the juvenile stage and greater in vitro response, making the performance of several experiments possible (GRATTAPAGLIA \& MACHADO, 1998). In vitro seed germination often allows greater seed germination than in nurseries, probably because in vitro conditions are more suitable for germination processes and early seedling development (NOLETO \& SILVEIRA, 2004), such as observed for Dendrocalamus membranaceus Munro (BRAR et al., 2013) and Cypripedium (ZENG et al., 2013).

Several studies have been conducted with in vitro germination of native species such as Hancornia speciosa Gomes (MACHADO et al., 2004; LÉDO et al., 2007a), Byrsonima intermedia A. Juss. (NOGUEIRA et al., 2004), Cereus jamacaru DC. (RÊGO et al., 2009), Genipa americana L. (ALMEIDA et al., 2013) and exotic species Moringa oleifera Lam. (FREIRE et al., 2008) and Azadirachta indica A. Juss. (LÉDO et al., 2008).

Plant acclimatization has been a great obstacle in in vitro micropropagation of many species. Substrate, due to its chemical, physical and biological characteristics, has great influence on adaptation and early development of plants under natural conditions. It is therefore crucial to determine the suitable substrates for acclimatization, which should ensure mechanical support of the root system, plant stability, supply of water and nutrients and gas exchange between roots and atmospheric air. The use of alternative substrates, which are viable for acclimatization, is of great important, since the use of agro-industrial residues in agricultural practices has proven to be an alternative to solve social and environmental problems (SILVEIRA et al., 2002).

The use of powdered coconut husk in the composition of substrates has been promising for the production of seedlings of different species (CORREIA et al., 2003; TERCEIRO NETO et al., 2004; BOMFIM et al., 2007; LÉDO et al., 2007b; SILVA et al., 2007). Besides high production, low cost and high availability, it is a suitable use for agroindustrial coconut residues (CARRIJO et al., 2002).

The aim of this study was to evaluate the effect of culture media on in vitro germination and the effect of different substrates on the acclimatization of two Myrciaria tenella types.

\section{MATERIAL AND METHODS}

The study was carried out at the Embrapa Tabuleiros Costeiros Laboratory of Plant Tissue Culture, Aracaju, SE. Seeds were extracted from fruits of two Myrciaria tenella types: Orange Type and Purple Type, derived from the natural population of Embrapa experimental field located in the municipality of Itaporanga d'Ajuda, Sergipe, Brazil $\left(11^{\circ} 07^{\prime} \mathrm{S}\right.$ and $\left.37^{\circ} 10^{\prime} \mathrm{W}\right)$.

After extraction, seeds were submitted to disinfection with $70 \%$ alcohol for 1 minute, $2-2.5 \%$ commercial sodium hypochlorite for 20 minutes and triple washing in sterile water. The seeds were inoculated in the following culture media: T1 MS medium $+30 \mathrm{~g} \mathrm{~L}^{-1}$ sucrose (MURASHIGE \& SKOOG, 1962), T2 - 1/2MS medium $+15 \mathrm{~g} \mathrm{~L}^{-1}$ sucrose and T3 - control without MS salts (0MS). After inoculation, the flasks were kept in a growth chamber $\left(25 \pm 2{ }^{\circ} \mathrm{C}, 12\right.$ hours light and luminous intensity of $\left.60 \mu \mathrm{mol} \mathrm{m} \mathrm{m}^{-2}\right)$.

The experiment was completely randomized in a 2x3 factorial design (two Myrciaria tenella types $\mathrm{x}$ three culture media) with five replicates. Each experimental plot consisted of two test tubes with one seedling each. The germination percentage and the height of seedling at 120 days after inoculation were evaluated.

To study the effect of substrates on acclimatization, the seedlings were transferred to plastic containers with capacity of $300 \mathrm{~cm}^{3}$ containing the following sterilized substrates: S1 -soil and powdered coconut husk - SPC (1:1 v/v); S2 - soil, washed sand and powdered coconut husk - SAPC $(1: 1: 1 \mathrm{v} / \mathrm{v} / \mathrm{v})$ and S3 - Biomix ${ }^{\circledR}$ commercial substrate - SC. The experiment was completely randomized in a 2x3 factorial design (two Myrciaria tenella types $\mathrm{x}$ three culture media) with five replicates. Each experimental plot consisted of two test tubes with one seedling each.

The seedlings were acclimatized for 60 days in shading greenhouse at $50 \%$ with micro 
sprinkler irrigation system. Supplementation of macro and micronutrients was held every seven days using a solution with half salt concentration of the MS medium. About 60 days after transfer to ex vitro conditions, the following evaluations were performed: survival percentage and number of leaf pairs.

The means of variables were submitted to analysis of variance and compared by the Tukey test at 5\% significance level using the SISVAR software (FERREIRA, 2011).

\section{RESULTS AND DISCUSSION}

\section{In vitro germination}

There was a significant effect of the culture medium on the in vitro germination percentage. In the absence of MS salts, there was $100 \%$ of germination percentage (Table 1). Similar results were observed for Hancornia speciosa Gomes native of northeastern Brazil (LÉDO et al., 2007a), Moringa oleifera (FREIRE et al., 2008) and Genipa americana L. (ALMEIDA et al., 2013), these species presented higher in vitro germination in the absence of MS salts. Whereas the cotyledons have the function of storing reserve substances to become autotrophic seedling, so the presence of nutrient solution in the external environment becomes unnecessary for the in vitro germination of cambui tree.

Another aspect to be considered is that the presence of MS salts and sucrose may have contributed to reduce the osmotic potential of the medium, reducing the availability of water for inhibiting the seed germination. According RAJJOU

Table 1 - In vitro germination percentage and height $(\mathrm{cm})$ of Myrciaria tenella seeds in different culture media.

\begin{tabular}{lccc}
\hline Culture medium & Orange type & Purple type & Means \\
\hline & ------ germination percentage--------- \\
MS $+30 \mathrm{~g} \mathrm{~L}^{-1}$ sucrose & 50.00 & 50.00 & $50.00 \mathrm{~B} *$ \\
$1 / 2 \mathrm{MS}+15 \mathrm{~g} \mathrm{~L}^{-1}$ sucrose & 50.00 & 50.00 & $50.00 \mathrm{~B}$ \\
$0 \mathrm{MS}+0 \mathrm{~g} \mathrm{~L}^{-1}$ sucrose & 100.00 & 100.00 & $100.00 \mathrm{~A}$ \\
Means & $83.33 \mathrm{a}$ & $83.33 \mathrm{a}$ & \\
VC $(\%)$ & 12.42 & & \\
Culture medium & --------------- height $(\mathrm{cm})-----------$ \\
$\mathrm{MS}+30 \mathrm{~g} \mathrm{~L}^{-1}$ sucrose & 3.25 & 2.64 & $2.95 \mathrm{~B}$ \\
$1 / 2 \mathrm{MS}+15 \mathrm{~g} \mathrm{~L}^{-1}$ sucrose & 3.33 & 4.95 & $4.14 \mathrm{~A}$ \\
$0 \mathrm{MS}+0 \mathrm{~g} \mathrm{~L}^{-1}$ sucrose & 2.95 & 3.30 & $3.13 \mathrm{AB}$ \\
Means & $3.17 \mathrm{a}$ & $3.76 \mathrm{a}$ & \\
VC $(\%)$ & 30.53 & & \\
\hline
\end{tabular}

*Means followed by the same capital letter in column and small letter in row do not differ from each other at $5 \%$ by the Tukey test. et al. (2012) the limited condition of presence of water allows sufficient hydration and increase of metabolic processes and repair preventing the germination.

No effect of Myrciaria tenella type on the germination percentage was observed. MACHADO et al. (2004) assessed the potential of in vitro propagation of 11 Hancornia speciosa Gomes matrixes native to the Brazilian Cerrado and observed 92.4\% germination in MS medium without growth regulators and no differences between the matrixes were observed.

The height of seedlings showed significant effect only for culture medium (Table 1). Seedlings kept in culture medium $1 / 2$ MS showed, on average, greater height development, with no differences between types and interaction between factors. The levels of organic and inorganic nutrients in in vitro culture media influenced various metabolic processes, showing effect on growth and tissues differentiation (MALDANER et al., 2006). Probably, reducing the concentration of salts in $50 \%$ had a positive effect on shoot growth.

Culture media without the presence of MS salts and half concentration of MS salts showed potential for the establishment of protocols for in vitro Myrciaria tenella propagation, lowering production costs due to its lower demand of salt concentration in the MS medium for the development of seedlings.

\section{Acclimatization}

There was no effect of Myrciaria tenella type, substrate or the interaction between factors on seedling survival in the acclimatization phase (Table 2). Although not statistically different, substrates added of powdered coconut husk (SPC and SAPC) showed numerical values greater than the commercial substrate. In studies conducted with coconut plants originated from zygotic embryo culture, LÉDO et al. (2007b) observed that the addition of powdered coconut husk to wash sand at a ratio of $1: 1(\mathrm{v} / \mathrm{v})$ led to higher plant shoot growth and more leaves. Saintpaulia ionantha Wendl seedlings showed good growth during acclimatization in Plantagro ${ }^{\circledR}$ and Bioplant ${ }^{\circledR}$ commercial substrates, followed by powdered coconut husk and vermiculite (TERCEIRO NETO et al., 2004).

There was an effect of Myrciaria tenella type on the emission of new leaves in seedlings in the acclimatization phase (Table 2). There was no effect of substrate or interaction of factors on the number of leaf pairs.

The Myrciaria tenella seedlings yellow type showed, on average, highest growth in leaf area 
Table 2 - Survival rate and number of leaf pairs emitted of Myrciaria tenella seedlings acclimated to different substrates.

\begin{tabular}{|c|c|c|c|}
\hline Substrate & Orange type & Purple type & Means \\
\hline & \multicolumn{2}{|c|}{-------------Survival rate-------------- } & \\
\hline $\mathrm{SPC} *$ & 91.67 & 83.33 & $87.50 \mathrm{~A} * *$ \\
\hline SAPC & 91.67 & 100.00 & $95.83 \mathrm{~A}$ \\
\hline $\mathrm{SC}$ & 90.91 & 69.23 & 79.17A \\
\hline Means & $91.43 \mathrm{a}$ & $83.78 \mathrm{a}$ & \\
\hline $\mathrm{VC}(\%)$ & 33.46 & & \\
\hline Substrate & \multicolumn{2}{|c|}{------Number of leaf pairs------- } & Means \\
\hline SPC & 3.58 & 2.33 & $2.95 \mathrm{~A}$ \\
\hline SAPC & 2.91 & 2.50 & $2.70 \mathrm{~A}$ \\
\hline $\mathrm{SC}$ & 3.00 & 2.15 & $2.54 \mathrm{~A}$ \\
\hline Means & $3.17 \mathrm{a}$ & $2.32 b$ & \\
\hline $\mathrm{VC}(\%)$ & 23.93 & & \\
\hline
\end{tabular}

* S1 - soil and powdered coconut husk - SPC (1:1 v/v); S2 - soil, washed sand and powdered coconut husk - SAPC $(1: 1: 1 \mathrm{v} / \mathrm{v} / \mathrm{v})$ and S3 - Biomix ${ }^{\circledR}$ commercial substrate - SC.

**Means followed by the same capital letter in column and small letter in row do not differ from each other at $5 \%$ by the Tukey test.

in the acclimatization phase with the emission of 3.17 leaf pairs. According SAEIDI (2008), the genetic variation and de vigor seed indicates the attempts to the genetically improve these seed quality traits that should be successful and optimistic in breeding programs. In genetic diversity studies of natural populations of Myrciaria tenella of yellow, orange and purple types, PINHEIRO et al. (2011) found a high genetic diversity among types. Probably, the yellow type showed a greater strength under acclimatization conditions of shading greenhouse.

\section{CONCLUSION}

For the in vitro sexual propagation and seedlings development of the Myrciaria tenella it is recommend the culture medium without MS salts and $1 / 2 \mathrm{MS}$ with sucrose $15 \mathrm{~g} \mathrm{~L}^{-1}$. All the substrates tested $\operatorname{SPC}(1: 1 \mathrm{v} / \mathrm{v}) ; \operatorname{SAPC}(1: 1: 1 \mathrm{v} / \mathrm{v} / \mathrm{v})$ and $\operatorname{Biomix}^{\circledR}$ are appropriated for seedlings acclimatization. The Myrciaria tenella yellow type showed highest growth in leaf area during acclimatization.

\section{ACKNOWLEDGEMENTS}

Thanks to the Brazilian Agricultural Research Agency (EMBRAPA) for allocating resources and Conselho Nacional de Desenvolvimento Científico e Tecnológico (CNPq)/ Fundação de Apoio à Pesquisa e à Inovação Tecnológica do Estado de Sergipe (FAPITEC-SE), for granting the scholarship.

\section{REFERENCES}

ALMEIDA, C.S. et al. Efeito do meio de cultura na germinação in vitro jenipapeiro. Scientia Plena, v.9, n.10, p.1-6, 2013. Available from: $\quad<$ http://www.scientiaplena.org.br/ojs/index.php/sp/article/ view/1537>. Accessed: Nov. 10, 2013.

APEL, M.A. et al.Anti-inflammatory activity of essential oil from leaves of Myrciaria tenella and Calycorectes sellowianus. Pharmaceutical Biology, v.48, n.4, p.433-438, 2010. Available from: <http://www.ncbi.nlm.nih.gov/pubmed/20645723>. Accessed: Jun. 20, 2013. doi: 10.3109/13880200903164386.

RAJJOU, L. et al. Seed germination and vigor. Annual Review Plant Biology, v.63, p.507-33, 2012. Available from: $<$ http://www.annualreviews.org/doi/pdf/10.1146/annurevarplant-042811-105550>. Accessed: Nov. 8, 2013. doi: 10.1146/ annurev-arplant-042811-105550.

BRAR, J. et al. In vitro seed germination of economically important edible bamboo Dendrocalamus membranaceus Munro. Indian Journal Experimental Biology, v.51, n.1, p.88-96, 2013. Available from: <http://www.ncbi.nlm.nih.gov/ pubmed/23441484>. Accessed: Nov. 8, 2013.

BOMFIM, G.V. do. et al. Aclimatização ex vitro de abacaxizeiro ornamental em substratos à base de pó-de-coco. Plant Cell Culture and Micropropagation, v.3, n.1, p.41-48, 2007. Available from: $<$ http://www.abctp.ufla.br/v3n1.pdf > Accessed: Jun. 23, 2013.

CARRIJO, O.A. et al. Fibra da casca de coco verde como substrato agrícola. Horticultura Brasileira, v.20, n.4, p.533-535, 2002. Available from: <http://www.scielo.br/pdf/hb/v20n4/14486.pdf $>$. Accessed: Jun. 20, 2013. doi: 10.1590/S0102-05362004000400015.

CORREIA, D. et al. Uso do pó da casca de coco na formulação de substratos para formação de mudas enxertadas de cajueiro anão precoce. Revista Brasileira de Fruticultura, v.25, n.3, p.557-558, 2003. Available from: <http://www.scielo.br/pdf/rbf/ v25n3/18695.pdf > Accessed: May. 25, 2013. doi:10.1590/S010029452002000200026

FERREIRA, D.F. SISVAR: a computer statistical analysis system. Ciência e Agrotecnologia, v.35, n.6, p.1039-1042, 2011. Available from: <http://www.scielo.br/scielo.php?pid=S141370542011000600001\&script=sci_arttext $>$. Accessed: Jul. 20, 2013. doi: 10.1590/S1413-70542011000600001.

FREIRE K.C.S. et al. Assepsia e germinação in vitro de moringa (Moringa oleifera Lam.). Cadernos de graduação, v.8, p.9-19, 2008.

GRATTAPAGLIA, D.; MACHADO, M.A. Micropropagação. In: TORRES, A.C. et al. Cultura de tecidos e transformação genética de plantas. Brasília, DF: Embrapa-SPI/Embrapa-CNPH, 1998. p.183-260.

LÉDO, A. da S. et al. Crescimento inicial de mangabeira (Hancornia speciosa Gomes) em diferentes meios de germinação in vitro. Ciência Agronômica, v.31, n.4, p.989-993, 2007a. Available from: <http://www.scielo.br/scielo.php?script=sci artt ext\&pid=S1413-70542007000400007>. Accessed: Jul. 31, 2013. doi: $10.1590 / \mathrm{S} 1413-70542007000400007$.

LÉDO, A. da S. et al. Cultivo in vitro de embriões zigóticos e aclimatação de plântulas de coqueiro anão. Pesquisa Agropecuária Brasileira, v.42, p.147-154, 2007b. Available from: 
$<$ http://www.scielo.br/scielo.php?script=sci_arttext\&pid=S0100204X2007000200002>. Accessed: Jul. 20, 2013. doi: 10.1590/ S0100-204X2007000200002.

LÉDO, A. da S. et al. Germinação in vitro de embriões zigóticos e sementes de nim indiano (Azadirachta indica A. Juss). Revista Brasileira de Plantas Medicinais, v.10, p.1-5, 2008. Available from: <http://www.sbpmed.org.br/download/issn_08_2/artigol_ v10n3.pdf $>$. Accessed: Out. 28, 2013.

LORENZI, H. Árvores brasileiras. São Paulo: Plantarum, 2000. V.1, p.264.

MACHADO, L. de L. et al. Seleção de matrizes e clones de mangabeira para o cultivo in vitro. Pesquisa Agropecuária Brasileira, v.39, n.5, p.431-435, 2004. Available from: <http:// www.scielo.br/pdf/pab/v39n5/a04v39n5.pdf>. Accessed: Jul. 25 , 2013. doi: 10.1590/S0100-204X2004000500004.

MALDANER, J. et al. Sacarose e nitrogênio na multiplicação in vitro de Pfaffia glomerata (Spreng.) Pedersen. Ciência Rural, v.36, n.4, p.1201-1206, 2006. Available from: <http:// www.scielo.br/scielo.php?pid=S010384782006000400024\&scr $\mathrm{ipt}=$ sci_arttext $>$. Accessed: May. 30, 2013. doi: 10.1590/S010384782006000400024.

MURASHIGE, T.; SKOOG, F. A revised medium for rapid growth and bioassays with tobacco tissue culture. Physiologia Plantarum, v.15, p.437-497, 1962. Available from: <http://onlinelibrary.wiley. com/doi/10.1111/j.1399-3054.1962.tb08052.x/pdf>. Accessed: Jul. 20, 2013. doi: 10.1111/j.1399-3054.1962.tb08052.

NOGUEIRA, R.C. et al. Germinação in vitro de murici-pequeno (Byrsonima intermedia A. Juss.). Ciência e Agrotecnologia, v.28, n.5, p.1053-1059, 2004. Available from: $<$ http://www.scielo. br/scielo.php?pid=S1413-70542004000500012\&script $=$ sci arttext>. Accessed: Jul. 20, 2013. doi:10.1590/S141370542004000500012 .

NOLETO, L.G.; SILVEIRA, C.E. dos S. Micropropagação de copaíba. Revista Biotecnologia Ciência \& Desenvolvimento, v.33, p.109-120, 2004. Available from: <http://www.biotecnologia. com.br/revista/bio33/copaiba.pdf>. Accessed: May. 30, 2013.

PINHEIRO, L.R. et al. Diversidade genética de uma população natural de cambuizeiro e avaliação pós-colheita de seus frutos. Scientia Plena, v.7, n.6, p.1-5, 2011. Available from: <http:// www.scientiaplena.org.br/ojs/index.php/sp/article/view/184/152>. Accessed: Oct. 30, 2013.

RÊGO, M.M.et al. In vitro seed germination of mandacaru (Cereus jamacaru DC.). Revista Caatinga, v.22, n.4, p.34-38, 2009. Available from: <http://periodicos.ufersa.edu.br/revistas/index. php/sistema/article/view/780/736>. Accessed: Nov. 10, 2013.

SAEIDI, G. Genetic variation and heritability for germination, seed vigor and field emergence in brown and yellow-seeded genotypes of flax. Plant Protection, v.2, n.1, p.15-22, 2008. Available from: $<$ http://www.biotecnologia.com.br/revista/bio33/copaiba.pdf $>$. Accessed: Nov. 8, 2013

SILVA, J.V. et al. Aclimatização "ex vitro" de mudas de antúrio em diferentes substratos. Revista Ciência Agronômica, v.38, n.2, p.188 191, 2007. Available from: <http://www.ccarevista.ufc.br/seer/index. php/ccarevista/article/view/134/129>. Accessed: May. 30, 2013.

SILVEIRA, E.B. et al. Pó de coco como substrato para a produção de mudas de tomateiro. Horticultura Brasileira, v.20, n.2, p.211-216, 2002. Available from: <http://www.scielo.br/pdf/hb/ v20n2/14450.pdf $>$. Accessed: Jun. 30, 2013.

ZENG, S. et al. Seed biology and in vitro seed germination of Cypripedium. Critical Reviews in Biotechnology, Early On Line, p.1-14, 2013. Available from: <http://informahealthcare.com/doi/ abs/10.3109/07388551.2013.841117>. Accessed: Nov. 15, 2013 doi:10.3109/07388551.2013.841117.

TERCEIRO NETO, C.P.C. et al. Efeito de diferentes substratos na aclimatação "ex vitro" de mudas de violeta africana (Saintpaulia ionantha Wendl). Revista de Biologia e Ciências da Terra, v.4, n.2, n.p. 2004. Available from: <http://eduep.uepb.edu.br/rbct/ sumarios/pdf/violetaafricana2.pdf>. Accessed: Jun. 30, 2013. 